\title{
Peningkatan Pendapatan Peternak Melalui Teknologi Integrasi Sapi-Sawit- Cacing Tanah Studi Kasus Di Desa Wonoharjo, Kecamatan Girimulya, Kabupaten Bengkulu Utara
}

\author{
Increased Revenue of Breeders through Integration Technology of Cow-Sawit-Earthworm. \\ Case Study in Wonoharjo Village, Girimulya District, North Bengkulu Regency
}

\section{U. Santoso, Jarmuji dan B. Brata}

Jurusan Peternakan, Fakultas Pertanian, Universitas Bengkulu Jalan Raya WR Supratman, Kandang Limun, Bengkulu

\begin{abstract}
This study aims to compare farmers' income on conventional business and cow palm-integration business in Wonoharjo Village, Girimulyo District, North Bengkulu Regency, Bengkulu Province. Two business models are compared. One group of conventional farmers with no additional technology (P1), and one group of farmers get additional technology in the form of business of cow-palm integration, where palm stem is used $50 \%$ as a substitute for grass, bran and sakura block and the utilization of cow dung as earthworm (P2). Total cost for P1 is $\mathrm{Rp} 4$ / 610.000, - and P2 Rp 8,344,750, - per year. Revenue for P1 is Rp 7 / 840.000, - and for P2 is Rp 35.600.000, - per year. Net income for P1 is Rp 269,166.67, - per month and for P2 is Rp 2,271,271 per month. It can be concluded that integrated effort increases farmer's income by $2.002 .104,33$ / month compared to conventional business.
\end{abstract}

Key words: Integration of cow palm, earthworm, vermicompost

\begin{abstract}
ABSTRAK
Penelitian ini bertujuan untuk membandingkan pendapatan petani pada usaha konvensional dan usaha integrasi sawit-sapi di Desa Wonoharjo Kecamatan Girimulyo, Kabupaten Bengkulu Utara, Propinsi Bengkulu. Dua model usaha dibandingkan. Satu kelompok petani usaha konvensional dengan tidak mendapatkan tambahan teknologi (P1), dan satu kelompok petani mendapatkan tambahan teknologi berupa usaha integrasi sapi-sawit, dimana pelepah sawit digunakan 50\% sebagai pengganti rumput, dedak ditambah sakura block dan pemanfaatan kotoran sapi sebagai media cacing tanah (P2). Total biaya untuk P1 adalah Rp 4/610.000,- dan P2 Rp 8.344.750,- per tahun. Pendapatan untuk P1 adalah Rp 7/840.000,- dan untuk P2 adalah Rp 35.600.000,- per tahun. Pendapatan bersih untuk P1 adalah Rp 269.166,67,- per bulan dan untuk P2 adalah Rp 2.271.271,- per bulan. Dapat disimpulkan bahwa usaha terintegrasi meningkatkan pendapatan petani sebesar 2.002.104,33/bulan jika dibandingkan dengan usaha konvensional.
\end{abstract}

Kata kunci: Integrasi sawit sapi, cacing tanah, vermikompos

\section{PENDAHULUAN}

Pemeliharaan ternak sapi di Desa Wonoharjo masih dilakukan dengan cara yang konvensional, padahal di desa tersebut membentang area perkebunan kelapa sawit. Pemberian pakan dilakukan dengan cara memotong rumput alam lalu diberikan kepada ternak (cut and carry sistem). Pakan yang diberikan hanya berupa rumput alam yang diperoleh di sekitar areal kebun kelapa sawit. Padahal rumput alam itu mempunyai kualitas gizi yang rendah (Santoso et al., 2005), sehingga pertambahan berat badannya sangat rendah. Untuk sapi Bali apabila diberi rumput saja hanya menghasilkan pertambahan berat badan sebesar 0,2 $\mathrm{kg} / \mathrm{hari}$ atau bahkan kurang dari itu. 
Selain usaha yang konvensional, kotoran sapi yang dihasilkan baru dimanfaatkan secara tradisional, yaitu dibuat menjadi pupuk dengan cara yang sederhana. Hal ini, tentu saja membuat usaha peternakan sapi di desa tersebut menghasilkan keuntungan yang relatif rendah.

Pada sisi lain, dengan bertambahnya umur tanaman kelapa sawit menyebabkan produksi biomasa rumput alam mengalami penurunan. Hal ini sesuai dengan pendapat Batubara (2003) bahwa potensi hijauan di bawah tanaman kelapa sawit ini berubah sejalan dengan tingkat umur pohon kelapa sawit diakibatkan adanya perbedaan intensitas sinar matahari yang diterima oleh hijauan.

Kondisi semacam ini menyebabkan jumlah pakan yang diberikan kepada ternak tidak mencukupi kebutuhan ternak dan menyebabkan produktivitas ternak menurun. Rata-rata produksi kelapa sawit milik anggota kelompok Desa Wonoharjo juga rendah, yaitu hanya 15 ton/hektar atau rata-rata 1.25 ton/bulan. Sementara rata-rata produksi tanaman kelapa sawit milik perusahaan perkebunan mencapai 27 ton/tahun. Produksi yang rendah ini disebabkan oleh dosis pemberian pupuk yang akibat terbatasnya kebutuhan stok pupuk kimia dipasaran dan harga pupuk yang mahal. Pada sisi lain, memiliki pengetahuan teknologi pemanfaatkan kotoran ternak menjadi pupuk organik pada tanaman kelapa sawit.

Kebun kelapa sawit dan sapi dapat diintegrasikan dalam suatu sistem integrasi
(Utomo dan Wijaya, 2012). Bangun (2010) melaporkan bahwa pendapatan petani yang mengintegrasikan kelapa sawit dan sapi jauh lebih tinggi daripada yang tidak terintegrasi. Faktor internal dalam sistem integrasi ini adalah kotoran sapi digunakan sebagai pupuk untuk kelapa sawit, adanya biomassa untuk pakan sapi dan sapi sebagai tabungan. Sistem integrasi ini akan lebih berdaya guna apabila sistem ini lebih dioptimalkan dengan memanfaatkan kotoran sapi sebagai media budidaya cacing tanah. Kotoran sapi merupakan media yang sangat baik untuk pertumbuhan cacing tanah (Brata, 2003, 2008). Selain menghasilkan vermikompos, cacing tanah yang dihasilkan juga dapat digunakan sebagai pakan ayam (Damayanti et al., 2009), dan ikan (Zakaria et al., 2012) dan bersifat antibakteri (Julendra dan Sofyan, 2007. Upaya integrasi sapi-sawit-vermikompos sangat mendukung upaya berkembangnya budidaya pertanian organik (Budiyanto, 2011; Mayrowani, 2012; Pangaribuan et al., 2012).

Berdasarkan uraian di atas, maka penelitian ini bertujuan membandingkan pendapatan petani pada dua model usaha yaitu usaha konvensional dan usaha terintegrasi.

\section{MATERI DAN METODE}

Desa Wonoharjo merupakan masyarakat yang rata-rata memelihara sapi Bali dan bekerja di kebun sawit. Pada penelitian ini digunakan dua kelompok 
petani, dimana setiap kelompok terdiri dari 20 kepala keluarga.

Dua model usaha dibandingkan. Satu kelompok petani usaha konvensional dengan tidak mendapatkan tambahan teknologi (P1), dan satu kelompok petani mendapatkan tambahan teknologi berupa usaha integrasi sapi-sawit, dimana pelepah sawit digunakan 50\% sebagai pengganti rumput, dedak ditambah sakura block (P2). Hasil penelitian pelepah sawit cukup baik untuk sapi (Astuti et al., 2016) dan dapat menggantikan rumput alam sebanyak 50\% (Jarmuji et al., 2015). Sakura block diberikan kepada sapi sebanyak 300 g/ekor/hari. Pakan diberikan sebanyak 10\% dari berat badan (Jarmuji et al., 2015). Pakan tambahan yang digunakan adalah sukura block. Sapi dipelihara selama 60 hari. Untuk pembuatan vermikompos digunakan cacing tanah Pheretima hupiensis, karena sangat efektif proses dekomposisi bahan organik (Anwar, 2009).

Formula sakura block yang digunakan disajikan pada Tabel 1.

\section{Tabel 1. Formula sakura block yang} digunakan

\begin{tabular}{ll}
\hline Bahan pakan & Jumlah(\%) \\
\hline Gula merah & 32 \\
Dedak & 28 \\
Tepung gaplek & 15 \\
Tepung jagung & 10 \\
Urea & 5 \\
Garam & 3 \\
TSP & 2 \\
Mineral mix & 2 \\
Topmix & 1 \\
Tepung daun katuk & 1 \\
Tepung kunyit & 1 \\
\hline
\end{tabular}

Kotoran sapi dikoleksi pada peternakan rakyat di Desa Wonoharjo sebagai media untuk cacing tanah. Media cacing tanah terdiri atas $70 \%$ kotoran dan $30 \%$ batang pisang. Setelah media siap digunakan, maka ditanam bibit cacing tanah sebanyak 2,5 kg Kandang cacing yang digunakan adalah sebanyak 2 kandang dan setiap kandang cacing terdiri dari 4 petak kandang cacing. Petak kandang cacing berukuran 1 x 2 m. Cacing tanah dipelihara selama 3 bulan.

Analisis pendapatan untuk dua model pemeliharaan (P1 dan $\mathrm{P} 2$ ) dianalisis secara deskriftif.

\section{HASIL DAN PEMBAHASAN}

\section{Performa Sapi dan Vermikompos}

Tabel 2 menyajikan data pertambahan berat badan, produksi cacing tanah, vermikompos dan pupuk kandang. P2 menghasilkan pertambahan berat badan yang lebih tinggi. Ini berarti pemberian sakura block dan dedak meningkatkan pertambahan berat badan sebanyak 0,3 kg/ekor/hari jika dibandingkan dengan P1.

Tabel 2. Performa dan produksi sapi, cacing tanah dan vermikompos

\begin{tabular}{lcc}
\hline Variabel & P1 & P2 \\
\hline $\begin{array}{l}\text { Pertambahan berat } \\
\text { badan sapi, } \\
\text { kg/ekor/hari }\end{array}$ & 0,2 & 0,5 \\
$\begin{array}{l}\text { Produksi cacing } \\
\text { tanah per 3 bulan, }\end{array}$ & \\
kg & \\
Vermikompos per & \\
$\begin{array}{l}\text { 3 bulan, kg } \\
\text { Pupuk kandang }\end{array}$ & 1500 \\
P1 = kelompok usaha konvensional dengan tidak \\
$\quad$ mendapatkan tambahan teknologi; \\
P2 = kelompok usaha terintegrasi
\end{tabular}




\section{Analisis Pendapatan}

Analisis pendapatan untuk dua konvensional dan usaha terintegrasi diperbandingkan.

model jenis usaha, yaitu usaha

Tabel 3. Biaya pemeliharaan satu ekor sapi dan pembuatan vermikompos

\begin{tabular}{|c|c|c|c|c|c|}
\hline No & Biaya-biaya & $\begin{array}{l}\text { Kebutuhan } \\
(\mathrm{kg})\end{array}$ & $\begin{array}{l}\text { Harga } \\
(\mathrm{Rp} / \mathrm{kg})\end{array}$ & P1 (Rp) & $\mathrm{P} 2$ (Rp) \\
\hline & Variable cost & & & & \\
\hline 1 & Rumput & $\begin{array}{l}7300(\mathrm{P} 1) \\
/ 3650(\mathrm{P} 2)\end{array}$ & 500 & 3.650 .000 & 1.825 .000 \\
\hline 2 & Dedak & 365 & 1.500 & & 547.500 \\
\hline 3 & Pelepah sawit & 3650 & 500 & & 1.825 .000 \\
\hline 4 & Sakura block & 109,5 & 3.500 & & 383.250 \\
\hline 5 & Tenaga kerja & & & 300.000 & 600.000 \\
\hline 6 & Bibit cacing & 20 & & & 2.000 .000 \\
\hline 7 & Media cacing & 6000 & & & 600.000 \\
\hline 8 & $\begin{array}{l}\text { Media pupuk } \\
\text { Fixed cost }\end{array}$ & 6000 & & 300.000 & \\
\hline 9 & $\begin{array}{l}\text { Penyusutan } \\
\text { kandang sapi }\end{array}$ & & & 300.000 & 300.000 \\
\hline 10 & $\begin{array}{l}\text { Penyusutan } \\
\text { kandang cacing }\end{array}$ & & & & 204.000 \\
\hline 11 & $\begin{array}{l}\text { Penyusutan alat- } \\
\text { alat }\end{array}$ & & & 60.000 & 60.000 \\
\hline & Total Biaya & & & 4.610 .000 & 8.344 .750 \\
\hline
\end{tabular}

Tabel 3 menyajikan biaya konvensional adalah Rp 4.610.000,-/tahun, pemeliharaan satu ekor sapi dan sedangkan untuk usaha terintegrasi adalah pembuatan pupuk kandang serta Rp 8.344.750,-/tahun. vermikompos. Biaya total untuk usaha

Tabel 4. Pendapatan kotor dua model usaha

\begin{tabular}{|c|c|c|c|c|c|c|c|}
\hline \multirow{2}{*}{ No } & \multirow[t]{2}{*}{ Komponen } & \multicolumn{2}{|c|}{ Jumlah (kg) } & \multicolumn{2}{|c|}{ Harga $(\mathrm{Rp} / \mathrm{kg})$} & \multirow{2}{*}{$\mathrm{P} 1$} & \multirow{2}{*}{$\mathrm{P} 2$} \\
\hline & & $\mathrm{P} 1$ & $\mathrm{P} 2$ & $\mathrm{P} 1$ & $\mathrm{P} 2$ & & \\
\hline 1 & $\begin{array}{l}\text { Sapi } \\
\text { (PBB/ekor) }\end{array}$ & 75 & 182,5 & 80.000 & 80.000 & 5.840 .000 & 14.600 .000 \\
\hline 2 & Pupuk kandang & 6.000 & & 333,33 & & 2.000 .000 & \\
\hline 3 & Vermikompos & & 6.000 & & 1.500 & & 9.000 .000 \\
\hline 4 & Cacing tanah & & 120 & & 100.000 & & 12.000 .000 \\
\hline & Total & & & & & 7.840 .000 & 35.600 .000 \\
\hline
\end{tabular}


Tabel 4 menyajikan perhitungan pendapatan kotor untuk masing-masing model usaha. Pendapatan kotor usaha konvensional adalah sebesar $\mathrm{Rp}$ 7.840.000,-/tahun, sedangkan untuk usaha terintegrasi sebesar Rp 35.600.000,-/tahun. Terdapat selisih pendapatan kotor yang sangat nyata antara kedua model usaha tersebut. Model usaha terintegrasi lebih tinggi sebesar Rp 27.760.000,-/tahun.
Tabel 5 menyajikan perbandingan pendapatan bersih dua model usaha. Usaha konvensional memperoleh pendapatan bersih sebesar $\mathrm{Rp} 3.230 .000$,-/tahun atau 269.166,67/bulan, dan usaha terintegrasi sebesar Rp 27.255.250,-/tahun atau Rp 2.271.271,-/bulan. Jadi usaha terintegrasi menghasilkan pendapatan yang lebih tinggi sebesar $=\operatorname{Rp} 2.271 .271-\operatorname{Rp} 269.166,67=$ Rp 2.002.104,33/bulan.

Tabel 5. Perbandingan pendapatan bersih antara usaha konvensional dan integrasi

\begin{tabular}{llll}
\hline No. & Komponen & P1 (Rp) & P2 (Rp) \\
\hline 1 & Pendapatan kotor & 7.840 .000 & 35.600 .000 \\
2 & Biaya total & 4.610 .000 & 8.344 .750 \\
3 & Pendapatan bersih & $3.230 .000 /$ tahun & $27.255 .250 /$ tahun \\
& & $269.166,67 /$ bulan & $2.271 .271 /$ bulan \\
\hline
\end{tabular}

P1 = kelompok usaha konvensional dengan tidak mendapatkan tambahan teknologi; P2 = kelompok usaha terintegrasi.

\section{KESIMPULAN}

Pendapatan bersih untuk P1 adalah Rp 269.166,67,- per bulan dan untuk P2 adalah Rp 2.271.271,- per bulan. Dapat disimpulkan bahwa usaha terintegrasi meningkatkan pendapatan petani sebesar 2.002.104,33/bulan jika dibandingkan dengan usaha konvensional.

\section{DAFTAR PUSTAKA}

Anwar, E. K. 2009. Efektivitas caing tanah Pheretima hupiensis, Edrellus sp, dan Lumbricus sp dalam proses dekomposisi bahan organik. J. Tanah Trop. 14 (2): 149-158.

Astuti, T. Y. Amir, Irdawati and U. Santoso. 2016. Nutritional improvement of palm oil fronds for ruminant feedstuffs using a local biotechnological approach. Pakistan J. Nutr. 15 (5): 450-454.

Bangun, R. 2010. Analisis Sistem Integrasi Sapi-Kebun Kelapa Sawit dalam Meningkatkan Pendapatan Petani di Kabupaten Rokan Hulu Propinsi Riau. Tesis. Program Pasca Sarjana, Universitas Andalas, Padang.

Batubara, L. P. 2003. Potensi integrasi peternakan dengan perkebunan kelapa sawit sebagai simpul agribisnis ruminan. Wartazoa, 13 (3): 83-91.

Brata, B. 2003. Pertumbuhan, Perkembangbiakan dan kualitas Eksmecat dari beberapa spesies Cacing Tanah pada Kondisi Lingkungan yag Berbeda. Disertasi. 
Pasca Sarjana Institut Pertanian Bogor.

Brata, B. 2008. Kualitas eksmecat dari beberapa spesies cacing tanah pada tingkat penyiraman dan pengapuran yang berbeda. JSPI, 3 (1): 43-48.

Budiyanto, M. A. K. 2011. Tipologi pendayagunaan kotoran sapi dalam upaya mendukung pertanian organik di desa Sumbersari Kecamatan Poncokusumo Kabupaten Malang. GAMMA 7 (1): 42-49.

Damayanti, E., A. Sofyan, H. Julendra dan T. Untari. 2009. Pemanfaatan tepung cacing tanah (Lumbricus rebellus) sebagai agensia antipullorum dalam imbunan pakan ayam broiler. JITV, 14 (2): 83-89.

Jarmuji, B. Brata dan U. Santoso. 2015. Penggunaan pelepah sawit dan Sakura block pada sapi Kaur dan pemanfaatan feses sapi Kaur sebagai media tumbuh cacing tanah. Laporan Hibah Bersaing Tahun 1, Universitas Bengkulu, Bengkulu.

Julendra, H dan A. Sofyan. 2007. Uji in vitro penghambatan aktivitas Escherichia coli dengan tepung cacing tanah (Lumbricus rubellus). Media Peternakan, 30 (1): 41-47.

Mayrowani, H. 2012. Pengembangan pertanian organik di Indonesia. Forum Penelitian Agro Ekonomi, 30 (2): 91-108.

Pangaribuan, D. H., M. Yasir dan N. K. Utami. 2012. Dampak bokashi kotoran ternak dalam pengurangan pemakaian pupuk anorganik pada budidaya tanaman tomat. J. Agron. Indonesia, 40 (3): 204-210.

Santoso, U., I. Badarina dan Warnoto. 2005. Pengaruh suplementasi ureamultinutrient (Sakura block) terhadap pertumbuhan kambing kacang. JITAA, 30 (3): 157-161.

Utomo, B. N dan E. Widjaja. 2012. Pengembangan sapi potong berbasis industri perkebunan kelapa sawit. J. Litbang Pert., 31 (4): 153161.

Zakaria, Z., N. H. M. Salleh, A. R. Mohamed, N. G. A. Anas and S, N. A. Idris. 2012. Optimization of protein content in earthworm based fish feed formulation for catfish (Clarius gariepinus). Sains Malaysiana, 41 (9): 1071-1077. 